Supplementary Information for:

\title{
Understanding sources of atmospheric hydrogen chloride in coastal spring and continental winter
}

\author{
Andrea A. Angelucci ${ }^{\dagger}$, Teles C. Furlani ${ }^{\dagger}$, Xuan Wang ${ }^{\ddagger \neq}$, Daniel J. Jacob ${ }^{+*}$, \\ Trevor C. VandenBoer ${ }^{\dagger}$, Cora J. Young ${ }^{\dagger}$
}

${ }^{\dagger}$ Department of Chemistry, York University, Toronto, Ontario, Canada

"School of Energy and Environment, City University of Hong Kong, Kowloon Tong, Hong

Kong

${ }^{\ddagger}$ School of Engineering and Applied Sciences, Harvard University, Cambridge, Massachusetts, USA

* Department of Earth and Planetary Sciences, Harvard University, Cambridge, Massachusetts, USA 


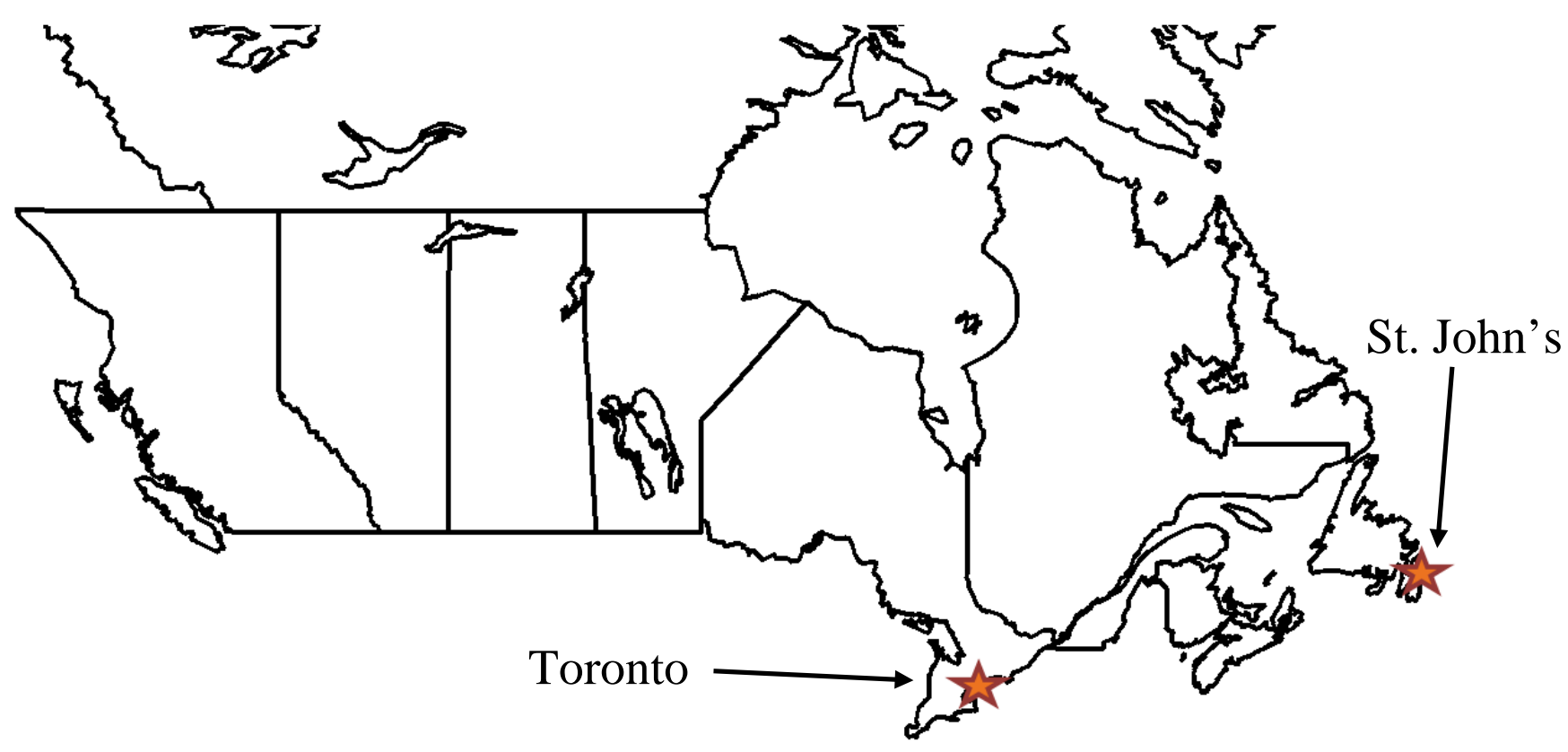

Figure S1: Map of sampling locations; Toronto, Ontario and St. John's, Newfoundland.

Table S1: Averages of various meteorological phenomena for our continental (Toronto) and coastal (St. John's) sampling periods.

\begin{tabular}{|c|c|c|c|c|c|}
\hline Location & Dates & $\begin{array}{c}\text { Average } \\
\text { Wind Speed } \\
\mathbf{( m / s )}\end{array}$ & $\begin{array}{c}\text { Average } \\
\text { Wind } \\
\text { Direction }\left({ }^{\circ}\right)\end{array}$ & $\begin{array}{c}\text { Average } \\
\text { Temperature } \\
\left({ }^{\circ} \mathbf{C}\right)\end{array}$ & $\begin{array}{c}\text { Average } \\
\text { Relative } \\
\text { Humidity } \\
\mathbf{( \% )}\end{array}$ \\
\hline St John's & $\begin{array}{c}\text { April 4-17, } \\
2017\end{array}$ & 6.4 & $196(\mathrm{SSW})$ & 2.6 & 85 \\
\hline $\begin{array}{c}\text { Toronto } \\
\text { (Period A) }\end{array}$ & $\begin{array}{c}\text { February 23- } \\
28,2018\end{array}$ & 3.1 & $195(\mathrm{SSW})$ & 4.6 & 62 \\
\hline $\begin{array}{c}\text { Toronto } \\
\text { (Period B) }\end{array}$ & $\begin{array}{c}\text { March 9-16, } \\
2018\end{array}$ & 2.9 & $279(\mathrm{~W})$ & -1.3 & 65 \\
\hline
\end{tabular}




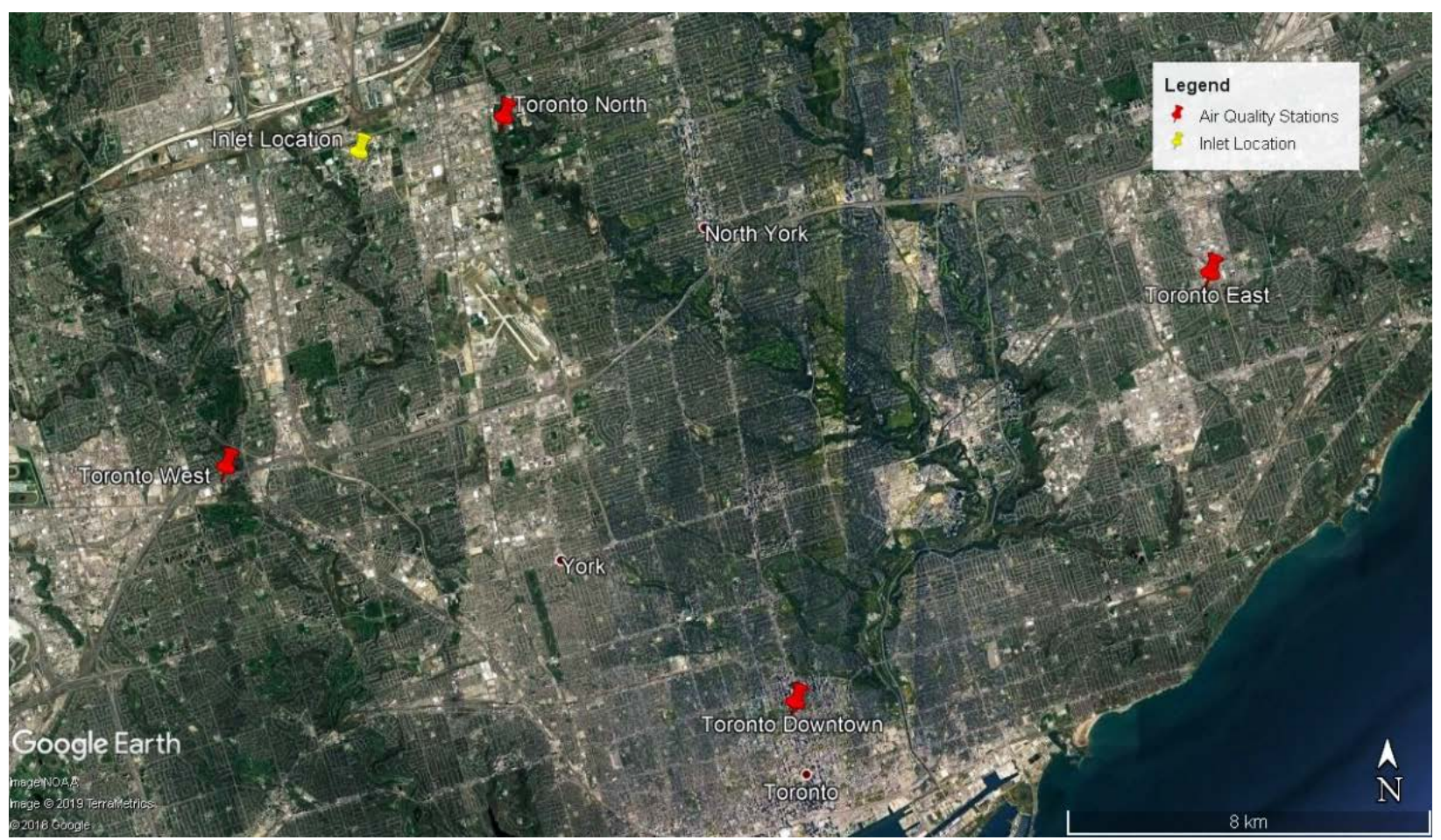

Figure S2: Map of the Toronto inlet location (yellow) as well as Toronto Air Quality Stations (red). Note that the only NO measurement reported was at the Toronto North Air Quality Station.

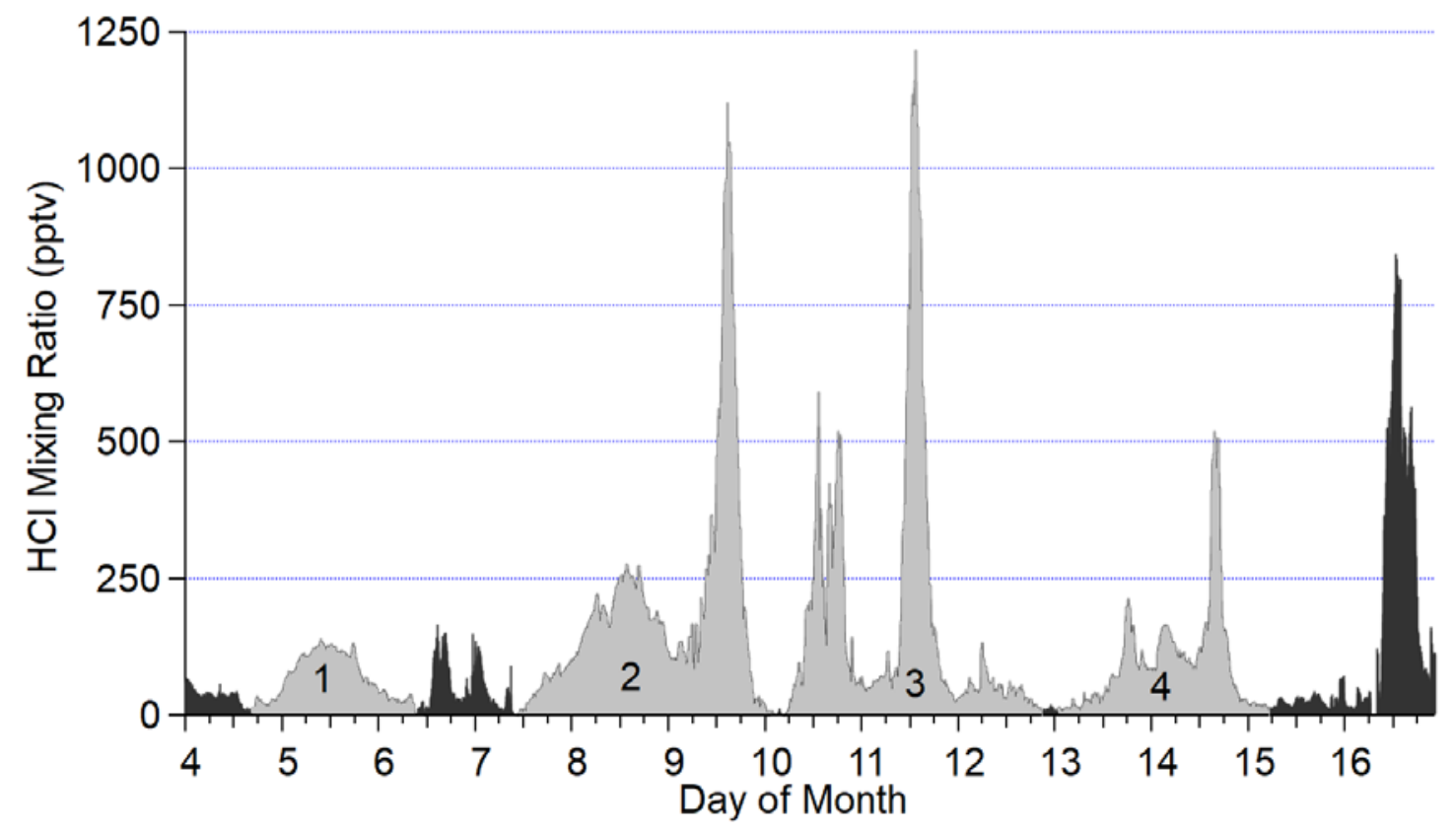

Figure S3: Five-minute average HCl data from April 2017 in St. John's. Multiday cycles are highlighted in grey and numbered. 


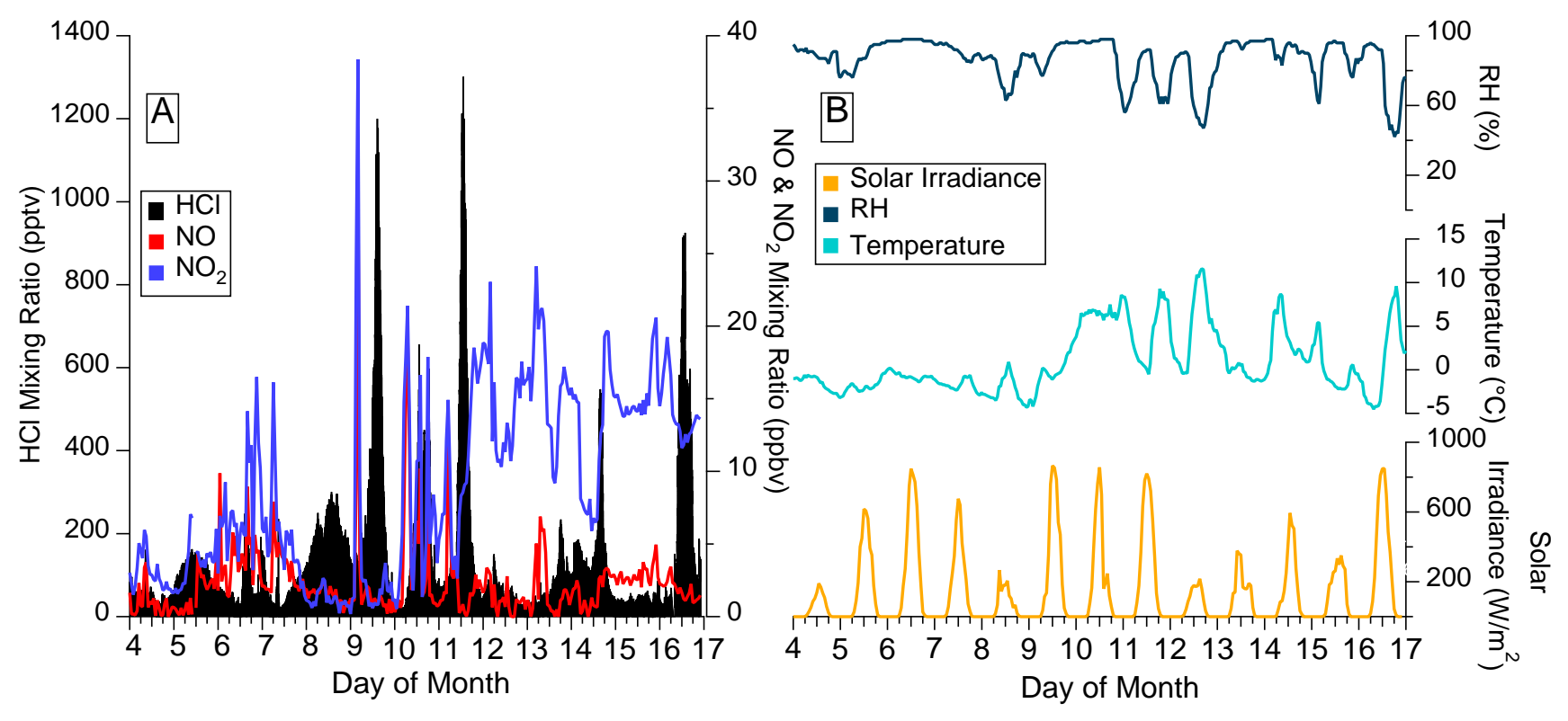

Figure S4: (A) Mixing ratios of $\mathrm{HCl}$ (black), $\mathrm{NO}$ (red), and $\mathrm{NO}_{2}$ (blue) as well as (B) Temperature (turquoise), RH (dark turquoise), and solar irradiance (orange) in St. Johns during the month of April.

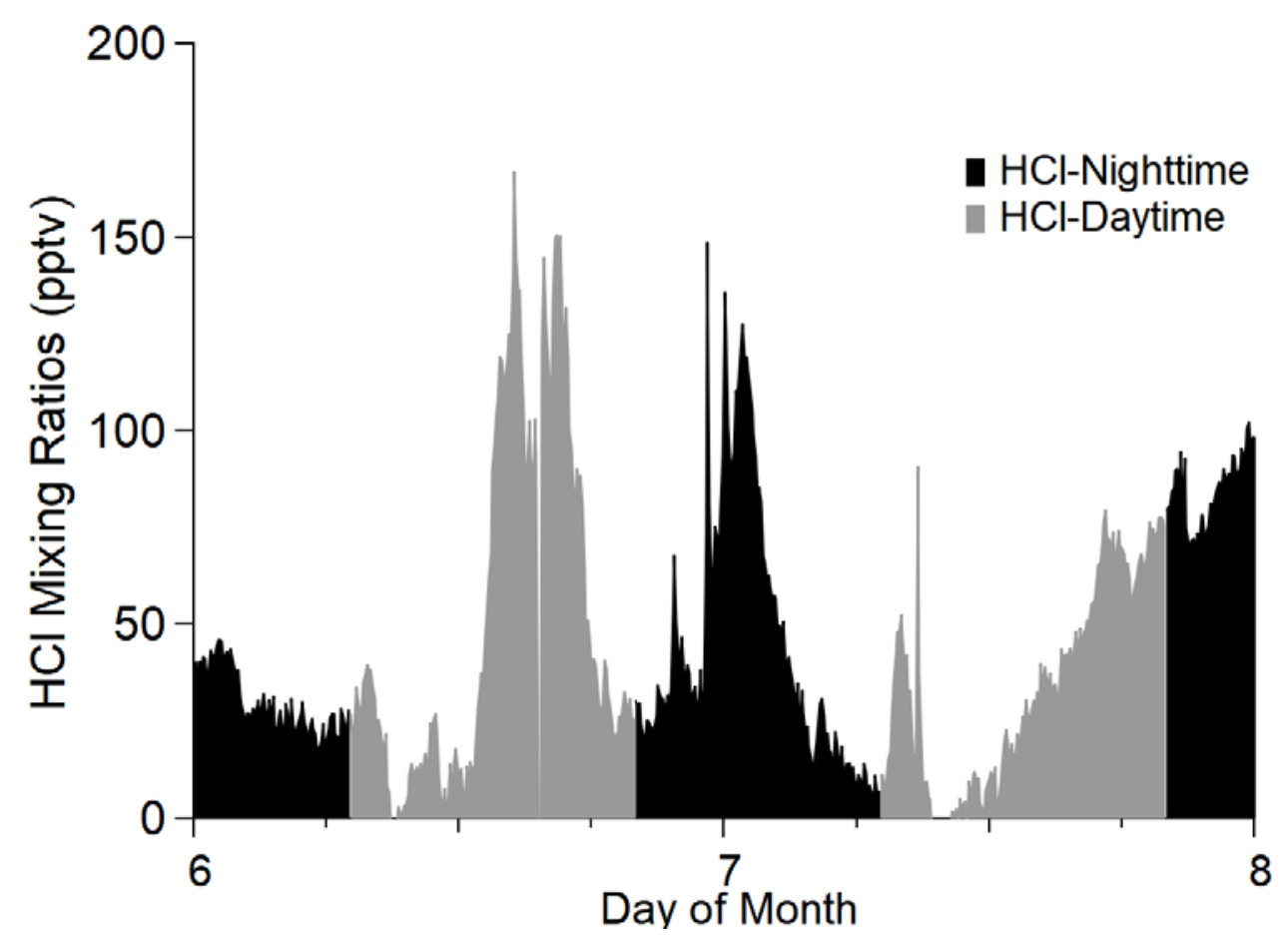

Figure S5: St. John’s daytime (grey) and nighttime (black) HCl mixing ratios for April 6-7, 2017. Just after midnight on April 7, 2017, an increase was observed that was attributed to a nearby building fire. 


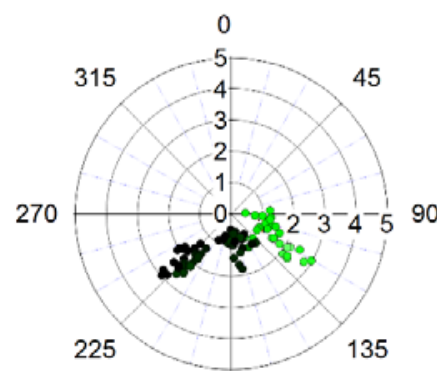

180

February 23

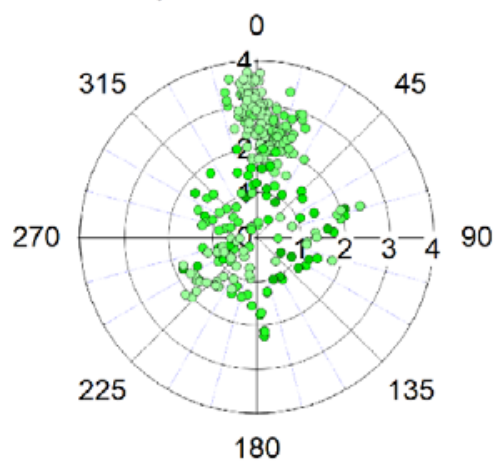

March 12

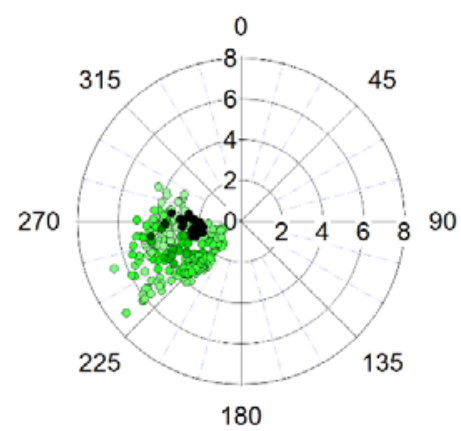

February 26

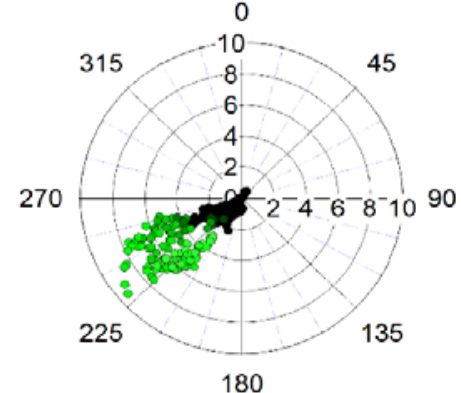

February 27

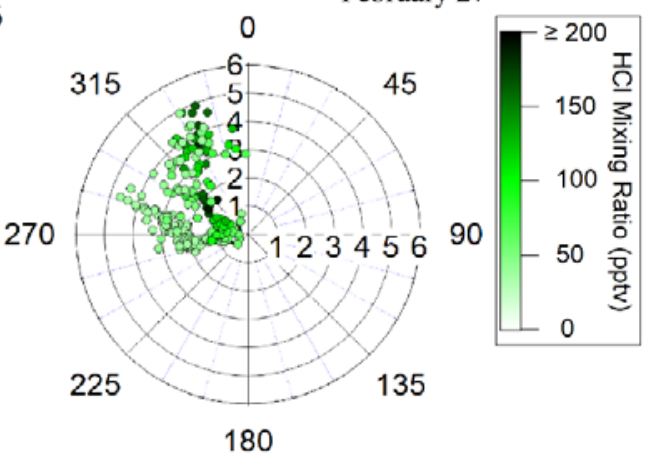

March 15

Figure S6: Toronto wind direction (degrees) and speed $(\mathrm{m} / \mathrm{s})$ for days in which elevated levels of $\mathrm{HCl}$ (white/green gradient) is also included. Data from February is part of Period A while data from March is part of Period B.
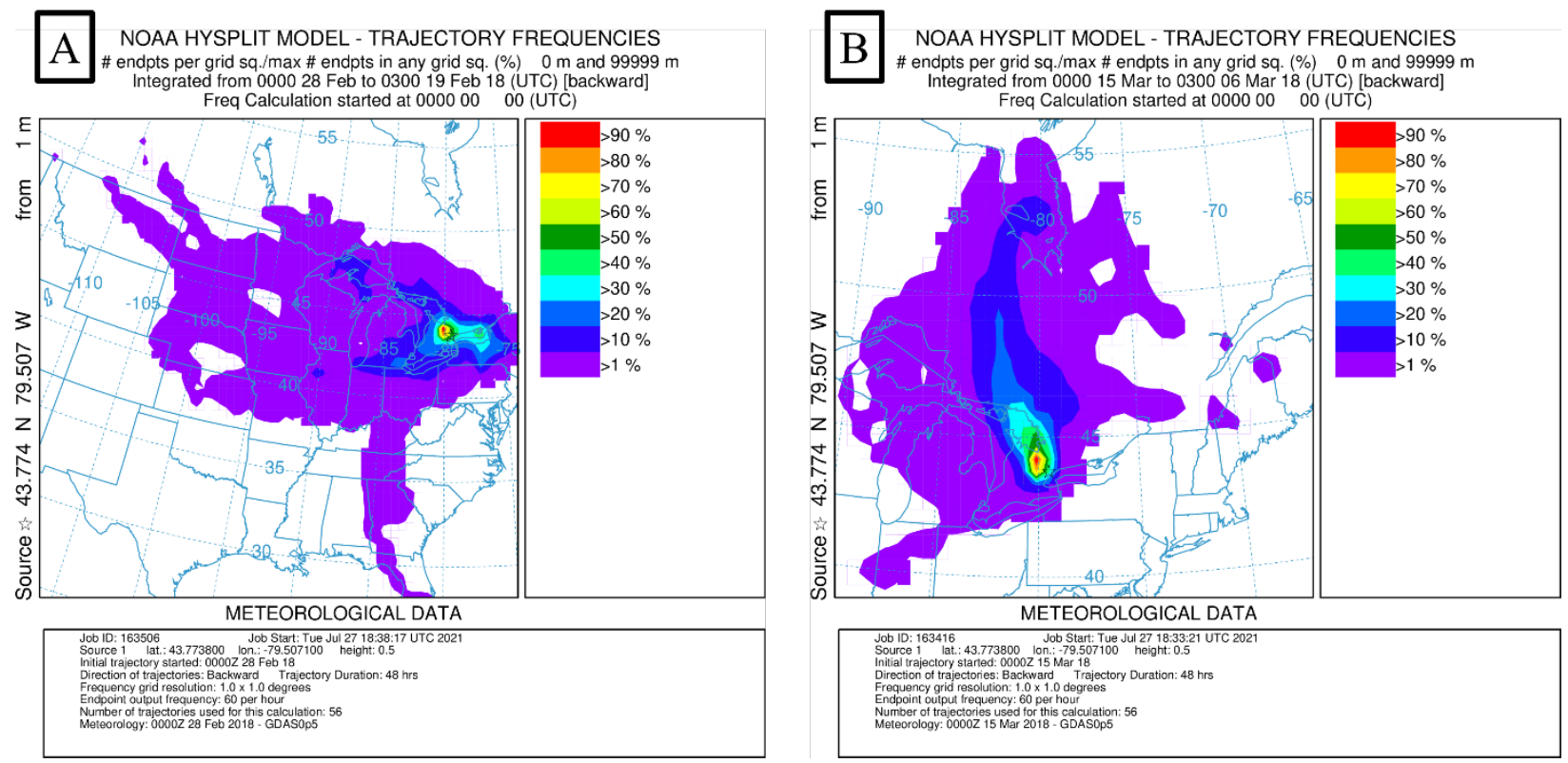

Figure S7: HYSPLIT back trajectories for one week since the last sampling day of Period A (A) and Period B (B) in Toronto 2018. 


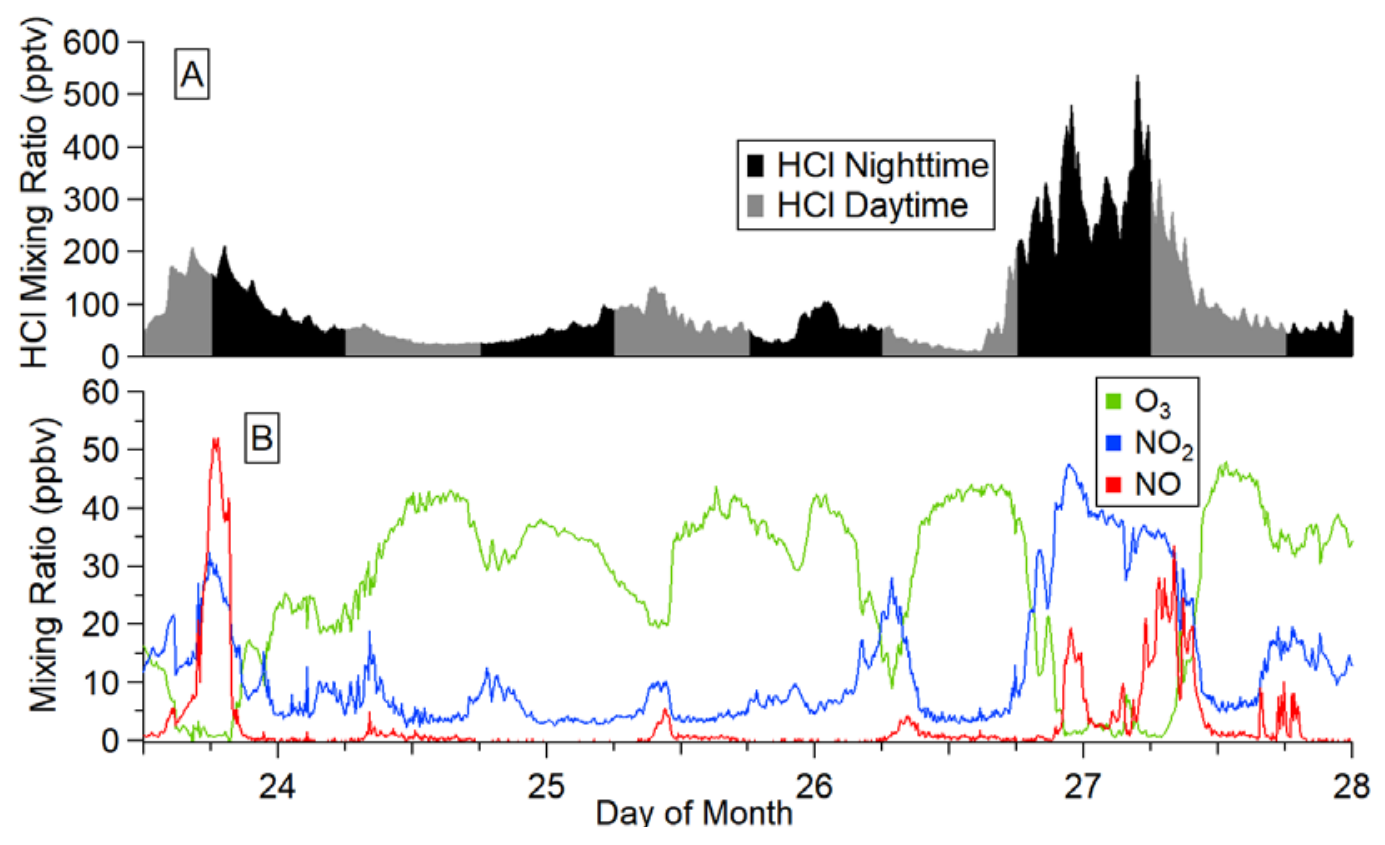

Figure S8: (A) Daytime (grey) and nighttime (black) mixing ratios of $\mathrm{HCl}$ for Toronto Period A. Daytime used here was from 7-18 h, representative of the average sunrise and sunset times for this observation period. (B) Mixing ratios of $\mathrm{NO}$ (red), $\mathrm{NO}_{2}$ (blue), and $\mathrm{O}_{3}$ (green).

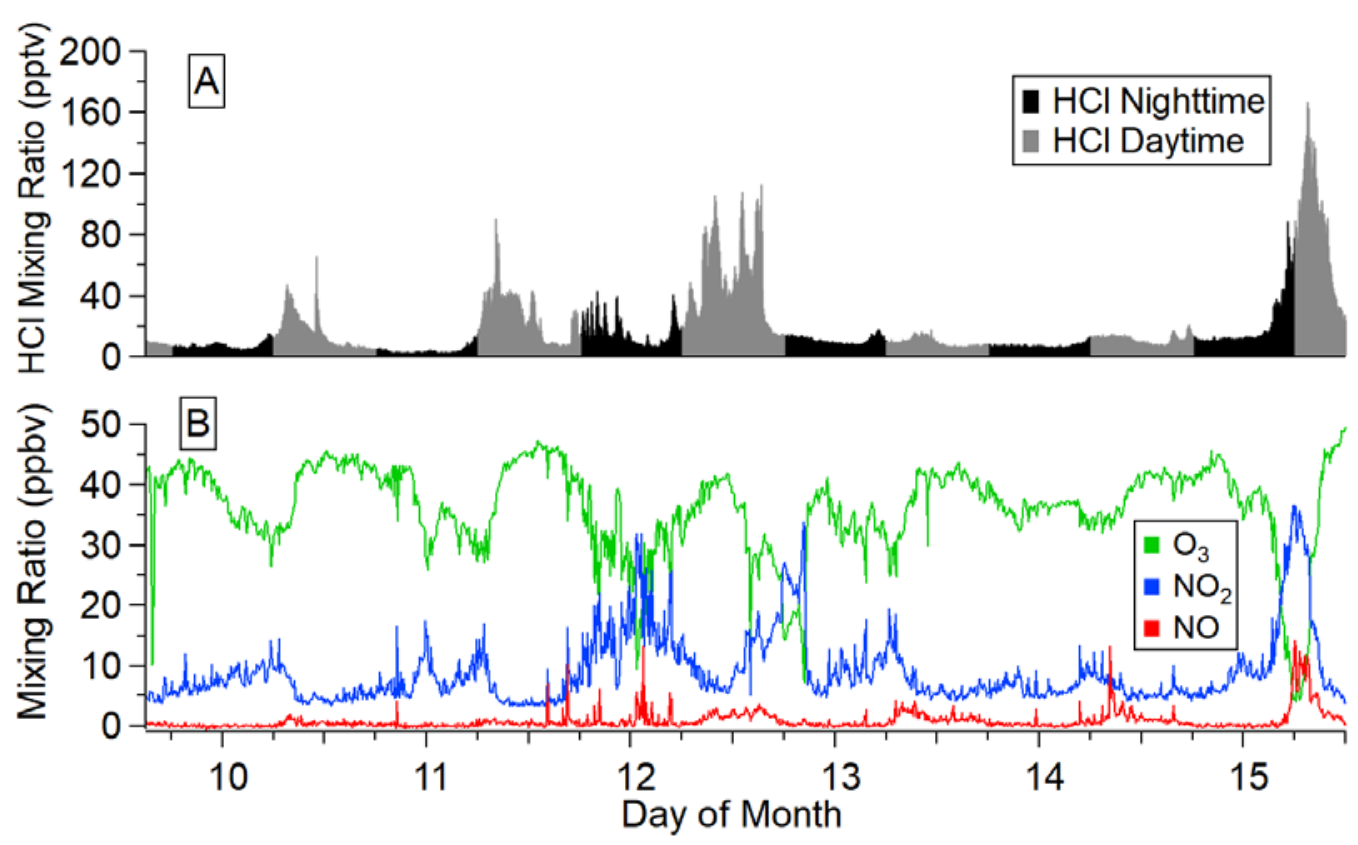

Figure S9: (A) Daytime (grey) and nighttime (black) mixing ratios of $\mathrm{HCl}$ for Toronto Period B. Daytime used here was from 7-18 h, representative of the average sunrise and sunset times for this observation period. (B) Mixing ratios of NO (red), NO2 (blue), and O3 (green). 
Table S2: T-Test data (average, standard deviations, and p-value) for the background levels of Period A and B in Toronto taken from diurnal plots for each period. Six of the lowest sequential points from both Figure 4A and B were taken as background measurements.

\begin{tabular}{|c|c|c|c|c|}
\hline $\begin{array}{c}\text { Average } \\
\text { Period A } \\
\text { (pptv) }\end{array}$ & $\begin{array}{c}\text { Standard } \\
\text { Deviation } \\
\text { Period A }\end{array}$ & $\begin{array}{c}\text { Average } \\
\text { Period B }\end{array}$ & $\mathbf{P}$ & $\begin{array}{c}\text { Standard } \\
\text { Deviation } \\
\text { Period B }\end{array}$ \\
\hline 74 & 4 & 11 & $1.20 \mathrm{E}-07$ & 0.92 \\
\hline
\end{tabular}

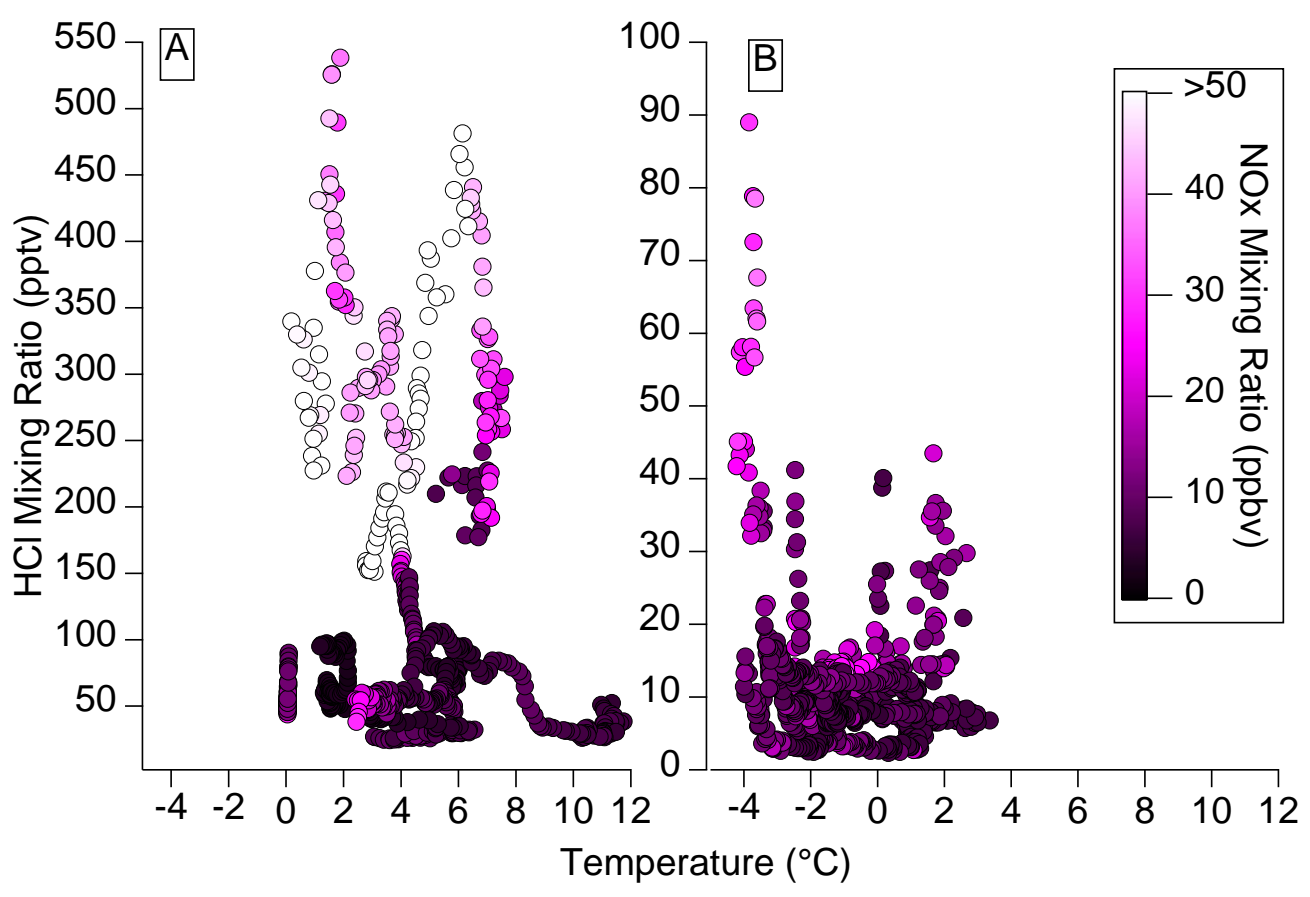

Figure S10: Nighttime $\mathrm{HCl}$ mixing ratios for Toronto A (A) and B (B) plotted against ambient temperature with a gradient of NOx mixing ratio. 

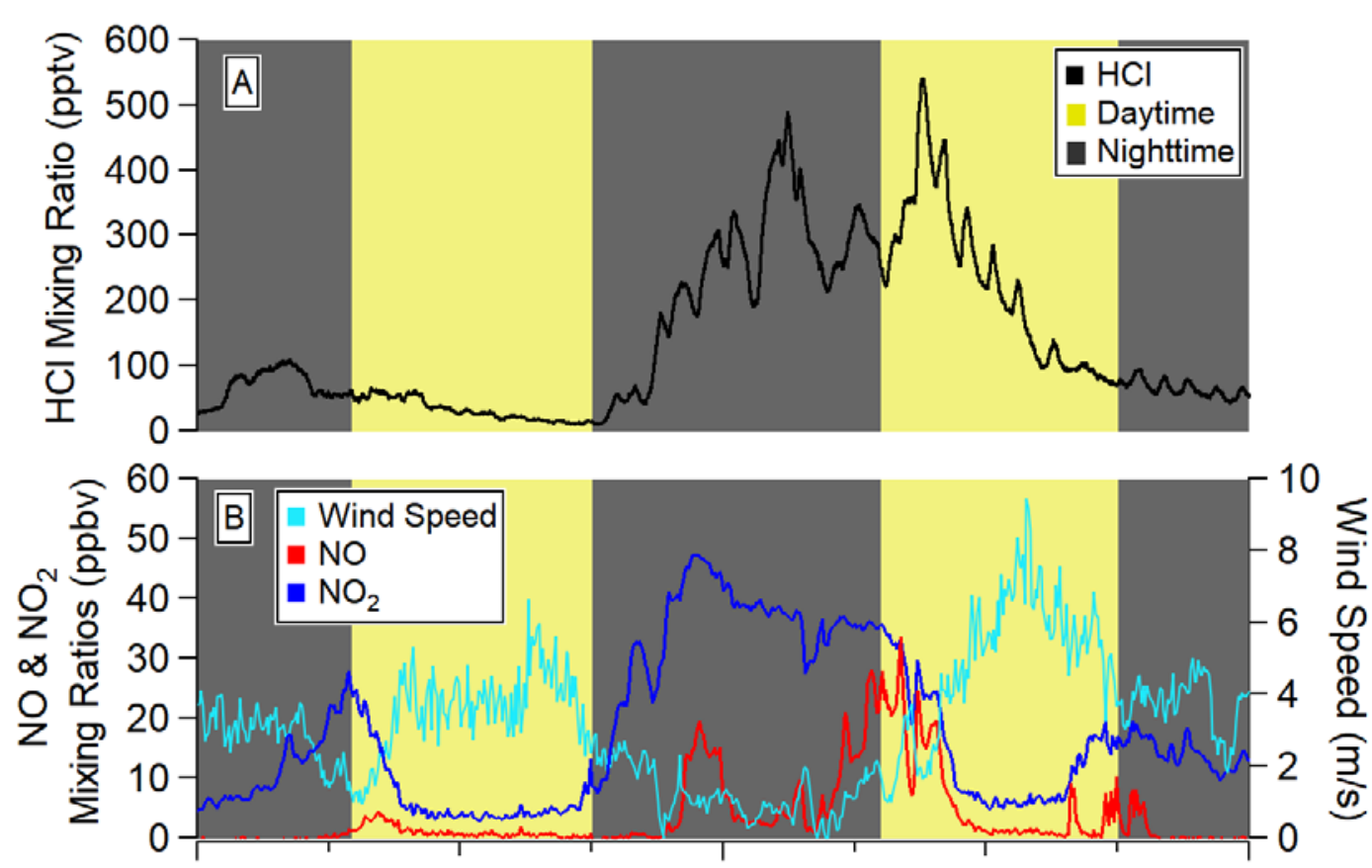

February 26

February 27

February 28

Figure S11: (A) HCl (black) mixing ratios for February 26-28, 2018 in Toronto. (B) NO (red), $\mathrm{NO}_{2}$ (blue), and wind speed (light blue) for the same time period. Daytime and nighttime are seen in yellow and grey, respectively. Daytime used here was from 7-18 h, representative of the average sunrise and sunset times for this observation period.

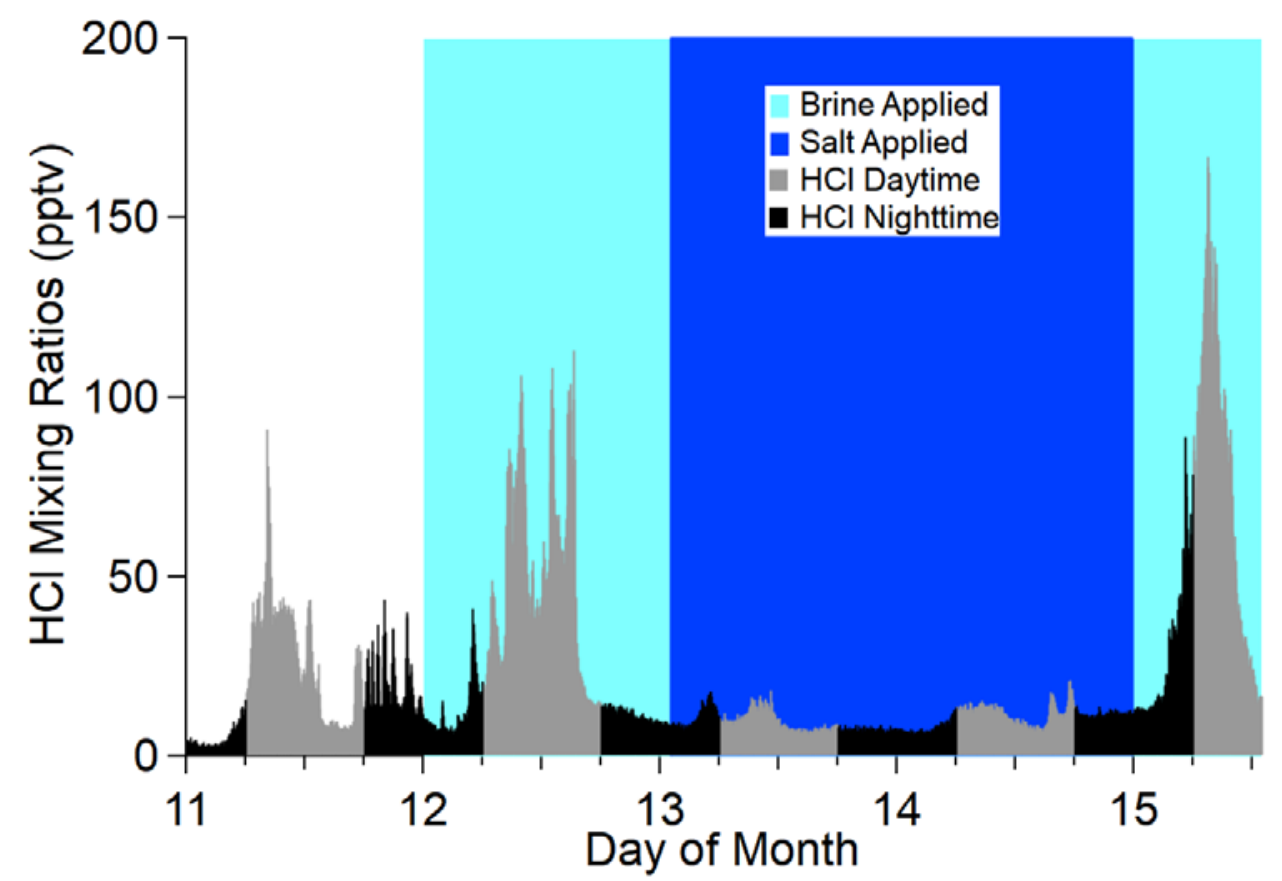

Figure S12: Toronto daytime (grey) and nighttime (black) HCl for Period B. Brine (mint) and salt applications have been highlighted. 


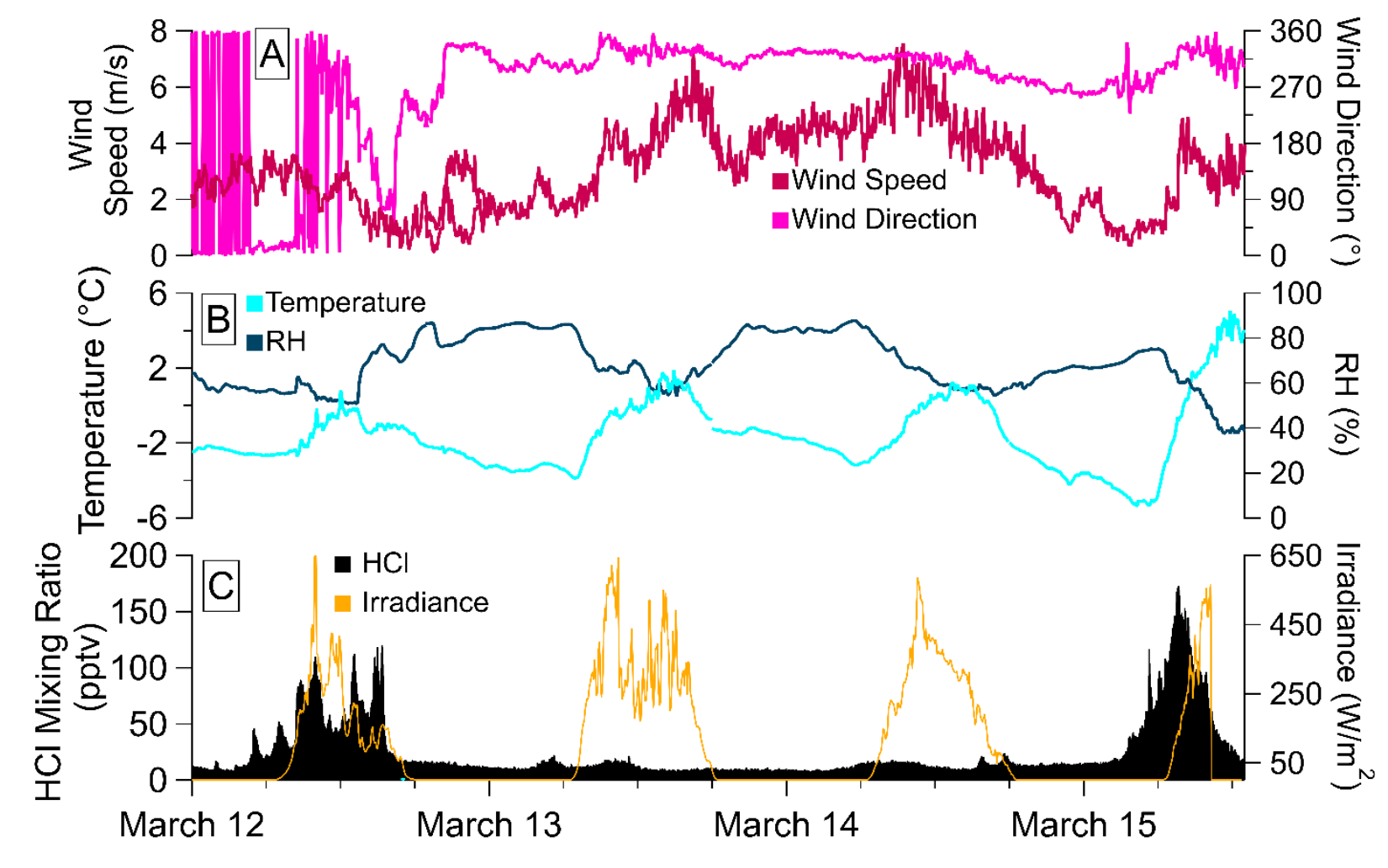

Figure S13: Measurements for March 12-15 2018 in Toronto in which road salt application was recorded. (A) Wind direction (pink) and speed (purple); (B) temperature (light blue) and RH (dark blue); (C) and $\mathrm{HCl}$ (black) with solar irradiance (orange). 


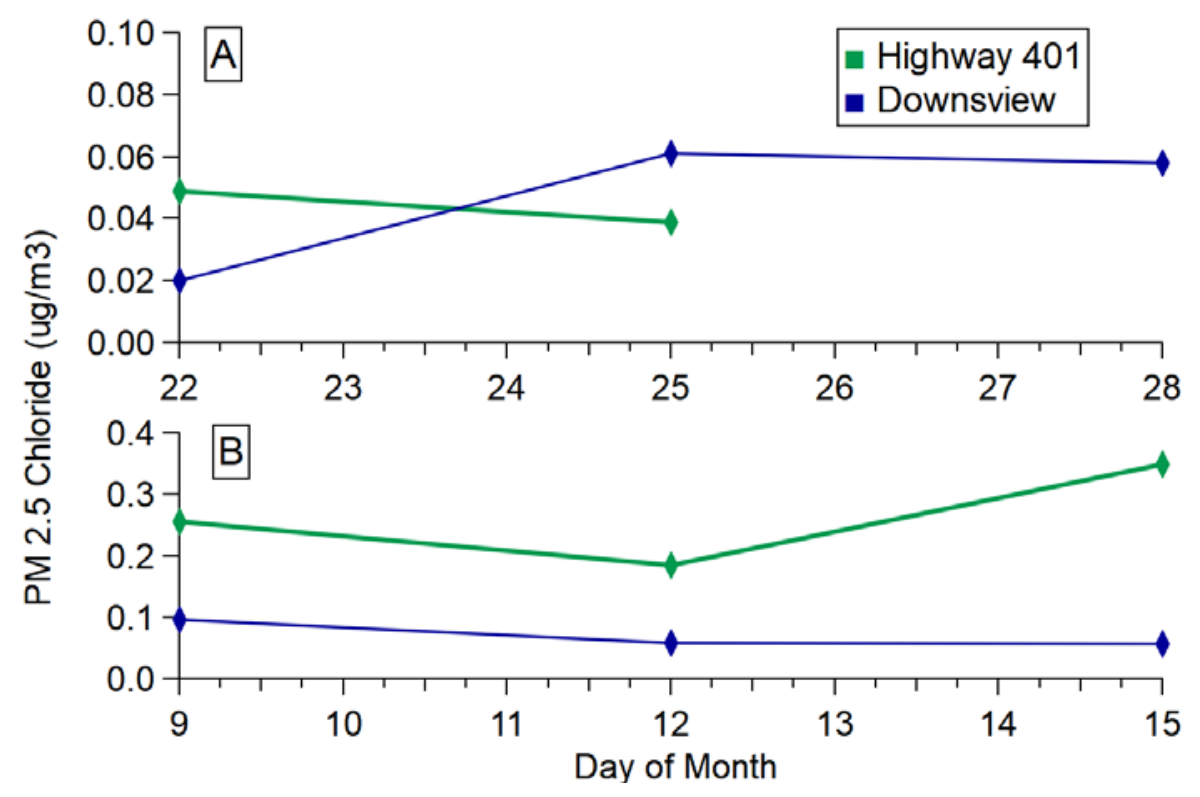

Figure S14: Mass concentrations of $\mathrm{PM}_{2.5}$ chloride collected in three-day intervals from the Downsview (blue) and Highway 401 (green) NAPS stations for Toronto A (Panel A) and B (Panel B) sampling periods. These sampling sites are co-located with air quality sites shown in Figure S2. Downsview is co-located with Toronto North and Highway 401 is co-located with Toronto West.

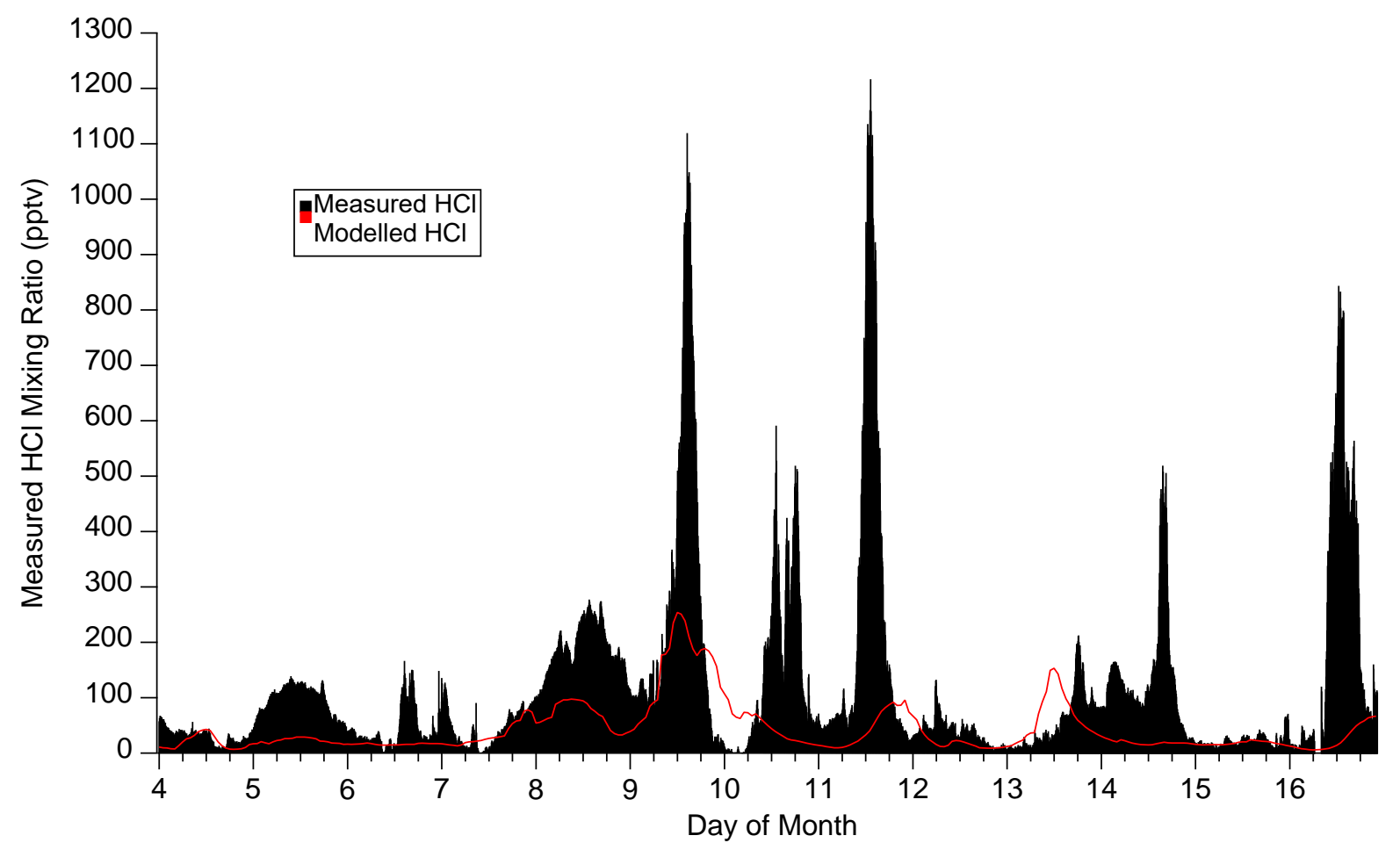

Figure S15: Measured (black) and modelled (red) mixing ratios of $\mathrm{HCl}$ in St. John's (coastal). 

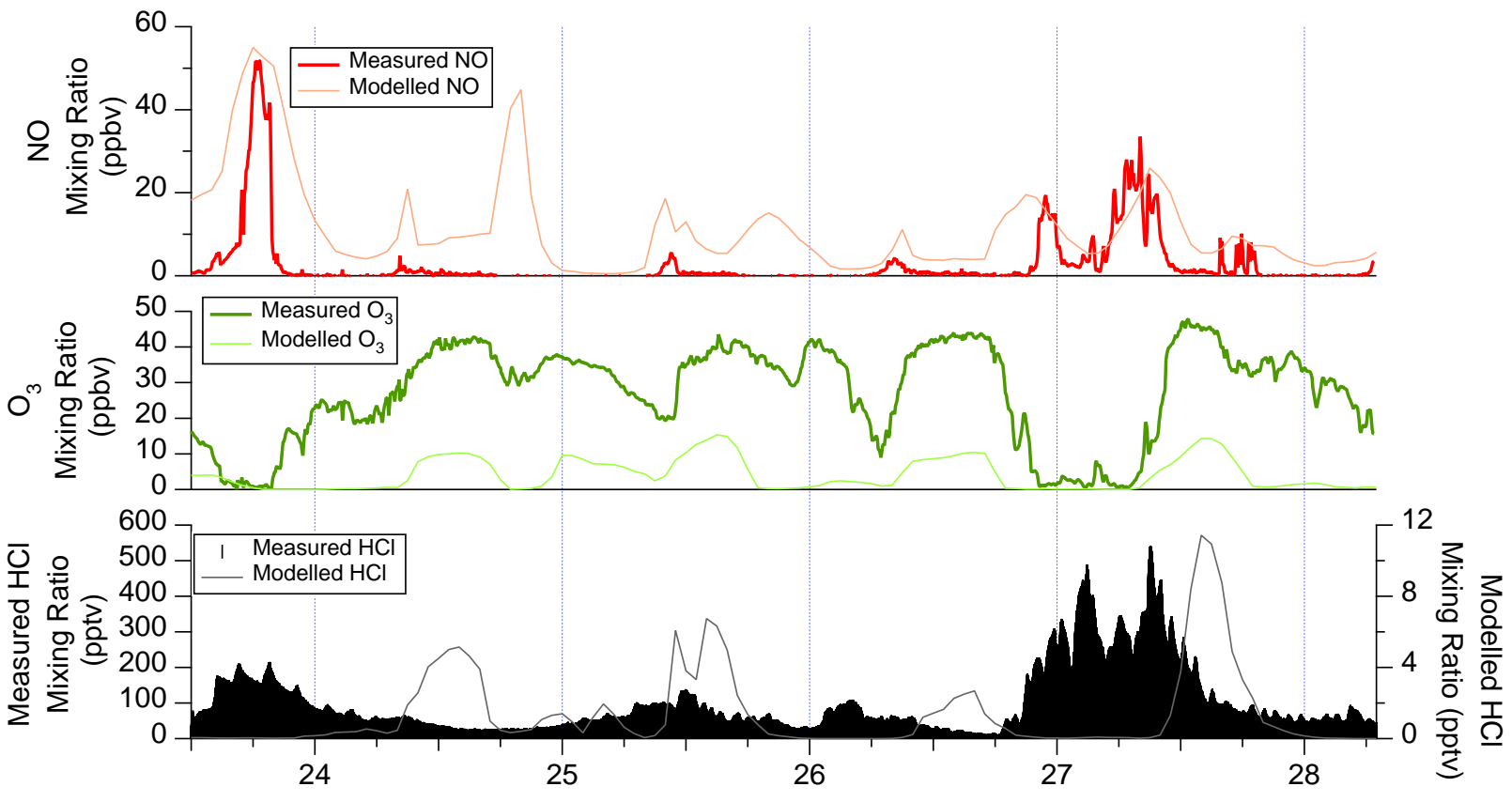

Day Of Month

Figure S16: Measured and modelled (GEOS-Chem) mixing ratios of NO (red and pink respectively), $\mathrm{O}_{3}$ (green and light green, respectively), and $\mathrm{HCl}$ (black and grey, respectively) for Toronto Period A.
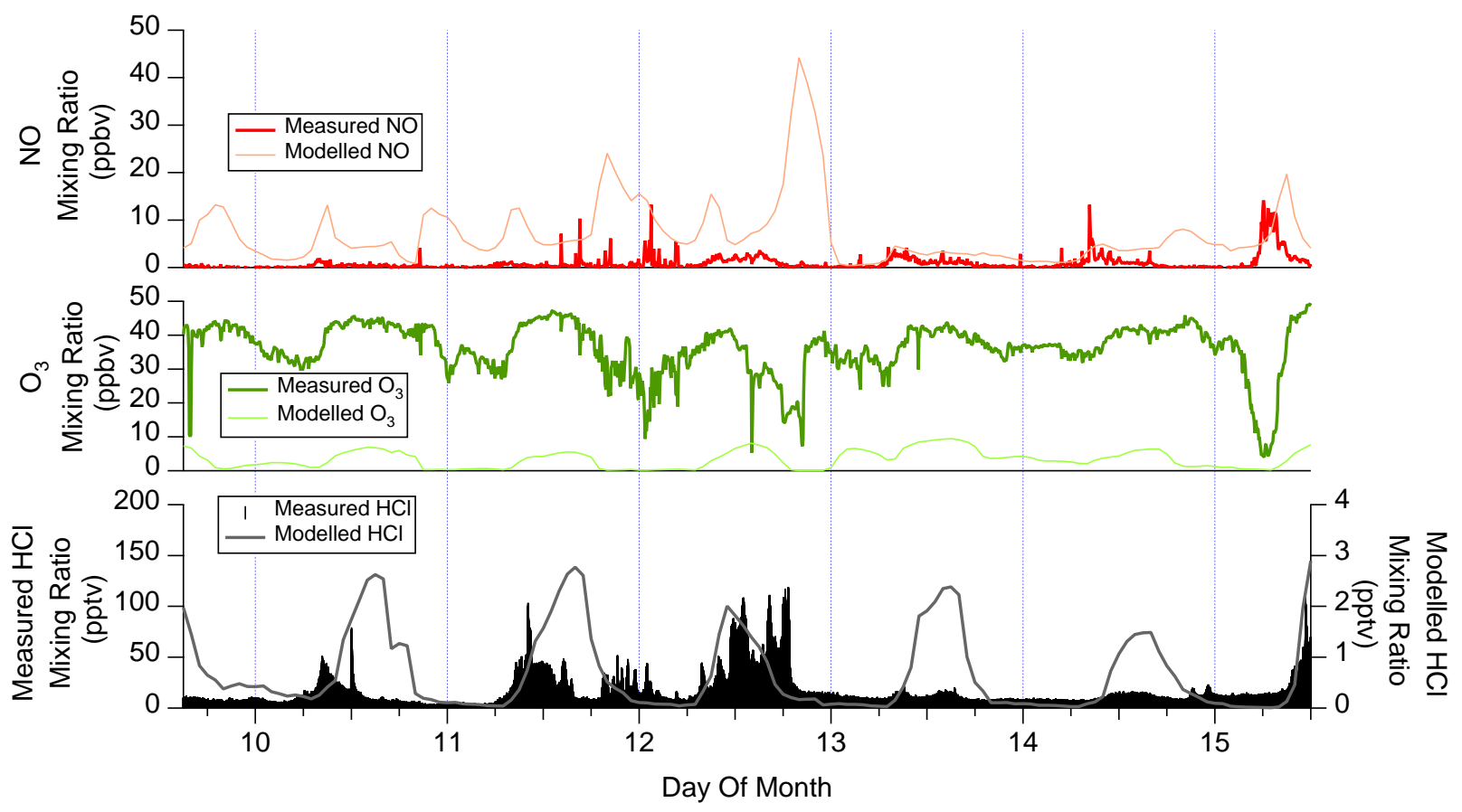

Figure S17: Measured and modelled (GEOS-Chem) mixing ratios of NO (red and pink respectively), $\mathrm{O}_{3}$ (green and light green, respectively), and $\mathrm{HCl}$ (black and grey, respectively) for Toronto Period B. 

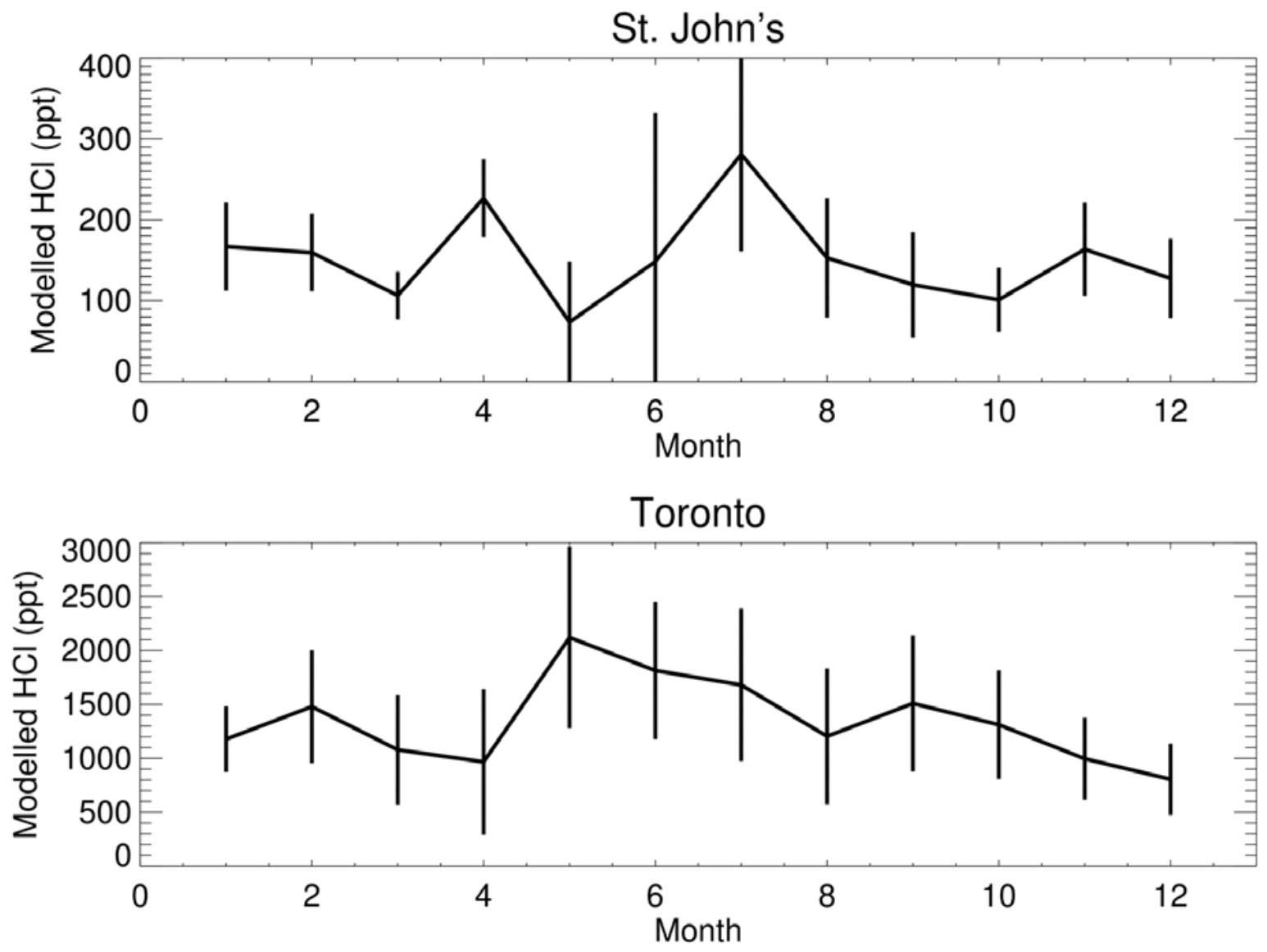

Figure S18: Monthly $\mathrm{HCl}$ mixing ratios for St. John’s and Toronto simulated by Hossaini et al. ${ }^{1}$

Table S3: T-Test data comparing modelled against measured $\mathrm{HCl}$ mixing ratios for St. John's and Toronto. Measured data was averaged onto the hourly timescale of the modelled data.

\begin{tabular}{|c|c|c|c|}
\hline & St. John's & $\begin{array}{c}\text { Toronto } \\
\text { A }\end{array}$ & $\begin{array}{c}\text { Toronto } \\
\text { B }\end{array}$ \\
\hline $\begin{array}{c}\text { Measured } \\
\text { Average } \\
\text { (ppbv) }\end{array}$ & 0.14 & 0.10 & 0.02 \\
\hline $\begin{array}{c}\text { Measured } \\
\text { Standard } \\
\text { Deviation }\end{array}$ & 0.16 & 0.09 & 0.02 \\
\hline $\begin{array}{c}\text { Modelled } \\
\text { Average } \\
\text { (ppbv) }\end{array}$ & 0.04 & 0.001 & 0.0007 \\
\hline $\begin{array}{c}\text { Modelled } \\
\text { Standard } \\
\text { Deviation }\end{array}$ & 0.04 & 0.002 & 0.0008 \\
\hline P & $1.61 \mathrm{E}-21$ & $3.38 \mathrm{E}-24$ & $1.40 \mathrm{E}-18$ \\
\hline
\end{tabular}



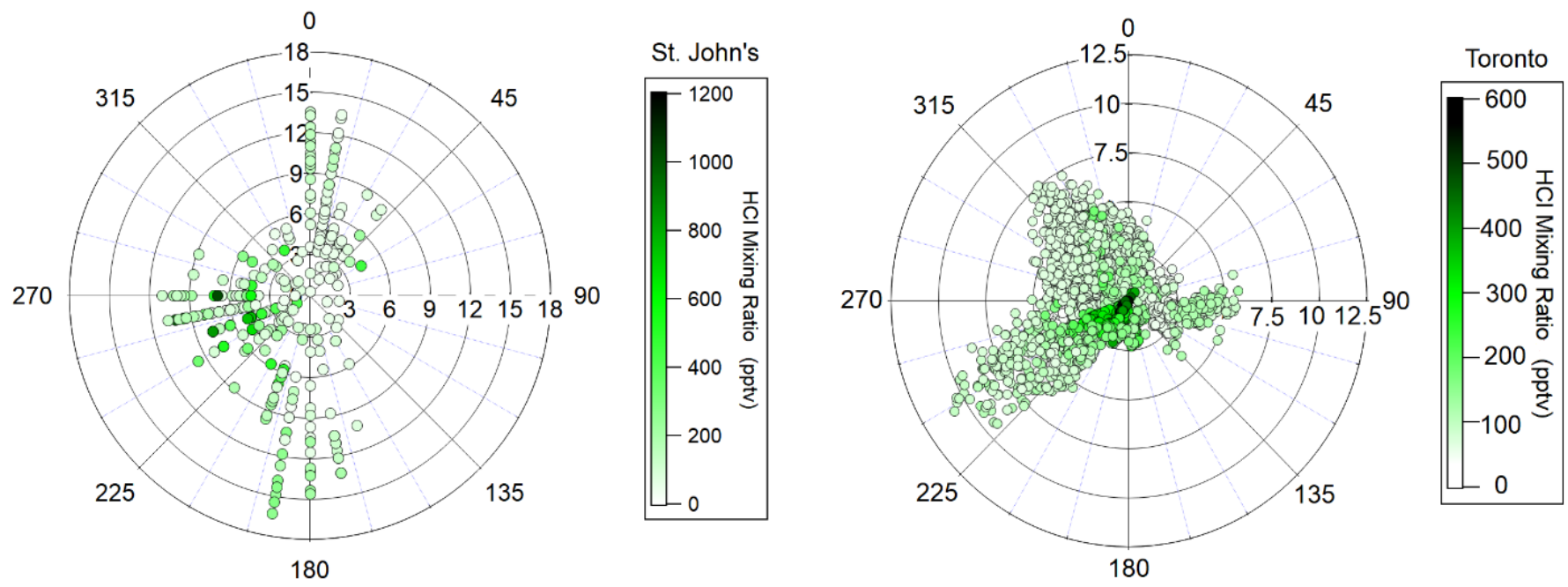

Figure S19: Wind direction (degrees) and wind speed (m/s) for St. John’s (daily) and Toronto.

\section{References}

(1) Hossaini, R.; Chipperfield, M. P.; Saiz-Lopez, A.; Fernandez, R.; Monks, S.; Feng, W.; Brauer, P.; Von Glasow, R. A Global Model of Tropospheric Chlorine Chemistry: Organic versus Inorganic Sources and Impact on Methane Oxidation. J Geophys Res 2016, 121 (23), 14,271-14,297. https://doi.org/10.1002/2016JD025756. 